\title{
Obituaries
}

\section{Norman Ashton}

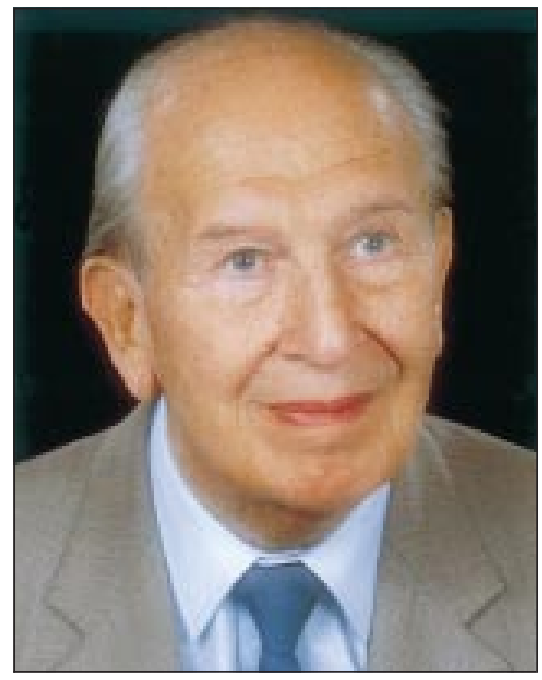

World leader in research into eye diseases and former director of pathology Institute of Ophthalmology, 1948-78 ( $b$ London 1913; $q$ Kings College/Westminster Hospital 1939; FRCP, FRCOphth; CBE, FRS, KStJ), $d 4$ January 2000 . He was pathologist to the Kent and Canterbury Hospital from 1941 to 1945 before doing military service with the Royal Army Medical Corps in west Africa and Egypt. He became director of pathology at the Institute of Ophthalmology in 1948 and built up a laboratory of international repute, which contributed to research and provided a clinical service to Moorfields Eye Hospital. He was responsible for the training of the first generation of ophthalmic pathologists in Britain. His major research was in diseases of the retinal blood vessels: diabetic retinopathy, hypertensive retinopathy, and the retinopathy of prematurity. He discovered that excessive oxygen given to compensate for breathing problems associated with premature birth can cause an obliteration of growing retinal blood vessels followed by disorganised regrowth and scarring. His observations led

\footnotetext{
Advice

We will be pleased to receive obituary notices of no more than 300 words. These will be submitted to an editorial committee and may be shortened. The BMJ will take responsibility for the shortening, but the name of the author who supplied the information will be given in brackets. We do not send proofs. Good quality, original, photographs are welcome.
}

to the careful control of oxygen delivery to premature babies. He was the first in Europe to identify Toxocara canis as a cause of retinal disease in children. Professor Ashton played a key part in establishing the European Pathology Society, of which he was made life president. A founder of Fight for Sight in 1965, he was chairman from 1980 to 1991 , when he became a patron. In honour of his work for the charity and his research achievements the new Institute of Ophthalmology building in Bath Street was named after him. He received many awards and prizes and was president of five medical societies of pathology and ophthalmology. For many years he was a steward at Westminster Abbey and was a popular after dinner speaker: his wit and immaculate delivery were legendary. After one speech in Baltimore, a fellow speaker, Bob Hope, said how grateful he was that Norman was not a professional comedian. $\mathrm{He}$ was a talented artist, taking special delight in still life paintings in oils, and to receive a photograph of his most recent effort in lieu of a Christmas card was a rare privilege. He was unmarried. [Adam Sillito, Phil Luthert]

\section{Robert Gregory Henderson}

Consultant physician, Dartford ( $b$ Clatt, Aberdeenshire, 1902; q Aberdeen 1929; DPH, MD; CBE), $d 26$ December 1999. After a visit to America in 1930 he became interested in assisted respiration and he and the hospital engineer built the first iron lung in Britain in their spare time. It was used to save the life of a boy in 1933. Lord Nuffield manufactured hundreds of the machines and they were provided to any hospital which requested one free of charge. He moved to London and became assistant medical officer at County Hall, responsible for upgrading many hospitals, including the evacuated hospital at Tindal House, Aylesbury, which later became Stoke Mandeville. He was later superintendent of the Southern Hospital in Dartford, which admitted more patients than any other hospital in England during Dunkirk and the blitz. He was made commanding officer of a naval unit at the hospital and appointed surgeon captain in the Royal Naval Volunteer Reserve, one of only two in the history of the reserve. When the hospital closed in 1959 to make way for the M20 Robert Henderson retired, married, and became a farmer and a propagator of roses. He leaves a wife, Josie, and three stepchildren. [Robert McLaren]

\section{Michael Herz}

General practitioner Israel ( $b$ London 1946; $q$ St Andrews/The London 1969), died suddenly while working in his garden on 7 September 1999. He was a principal in west London and a member of the Balint Society, whose psychodynamic approach influenced his professional outlook. In 1980 he emigrated to Israel where he became head physician and director of the Clalit Health Fund clinics in his area. He and his family eventually settled in a village in the Sharon Valley where he was able to tend his large garden as well as his patients. When he arrived in Israel academic family medicine was in its infancy, and he contributed to its development, firstly as regional director of a vocational training scheme, and later as deputy director of the department of general practice at the Rabin Medical Centre. More recently, he became director of the postgraduate diploma programme in family medicine at Tel Aviv University. He was an exceptionally accessible and supportive person with a wonderful sense of humour. He interests included music, woodwork, walking, and gardening. He leaves a wife, Sandra, and four children. [MichaEL WEINGARTEN]

\section{Maurice Wingate Paterson}

Former consultant ophthalmologist and honorary lecturer Glasgow ( $b$ Brechin 1911; $q$ Edinburgh 1937; FRCSEd, FRCOphth), died from metastatic cancer in the bone on 5 December 1999. He served in the Royal Army Medical Corps during the war, was mentioned in dispatches, and left with the honorary rank of major. He trained in ophthalmology in Sheffield and Edinburgh and when he moved to the Western Infirmary in Glasgow he was particularly interested in the effects on the eye of hypertension and diabetes and in perimetry. From 1962 to 1976 he was a consultant at the Glasgow Eye Infirmary and Stobhill Hospital, where he was a meticulous and skilled surgeon. When he retired Maurice returned to live in Edinburgh and worked part time for over 10 years in the supplementary ophthalmic services. In his study he could lay his hands on something to interest everyone; he loved literature and gave great pleasure when he recited poetry. He was also a fine artist and painted retinal illustrations in textbooks. When he retired he attended the Edinburgh College of Art to learn etching. Predeceased 
by his wife, Jenny (also a doctor), he leaves four children and seven grandchildren. [JOAN CAMPBELL]

\section{Gerald Barcroft Robinson}

General practitioner Knaresborough ( $b$ 1908; $q$ Cambridge/Leeds 1937), $d 22$ December 1999. At school he captained the rugby team for three years, during which time it was unbeaten. He joined his father's practice in Knaresborough and then served in the Royal Army Medical Corps from 1941 to 1945 , ending with the rank of major. At one stage he was surgeon to the commander in chief in India, General Auchinleck. After the war he returned to general practice where he remained until his retirement in 1973 . He travelled extensively after he retired, pursuing his interests in wildlife and wild places, and, in particular, ornithology. He continud to lead a full and active life and he and his wife celebrated their diamond wedding anniversary in August 1999. He leaves a wife, Joy; three sons; and seven grandchildren. [J B RoBINSON]

\section{Robert Joseph Smith}

Former general practitioner London ( $b$ 1923; $q$ Liverpool 1947), died from acute interstitial pneumonitis on 6 October 1999. After national service in the Royal Air Force, Bob entered general practice in Brixton in 1950. The partnership moved to a new health centre at Myatts Field in 1984, where he remained until he retired in 1988 . He thrived on the challenge of a busy inner city practice and had a strong following among his patients, who benefited from his humour and commonsense as well as his clinical acumen. Despite some health problems caused by Guillain-Barré syndrome, Bob enjoyed his retirement with interests in travel, the history of art, and his garden. He leaves a wife, Betty; two children (one a general practitioner); and five grandchildren. [JuDITH FRENCH]

\section{William Deane Steel}

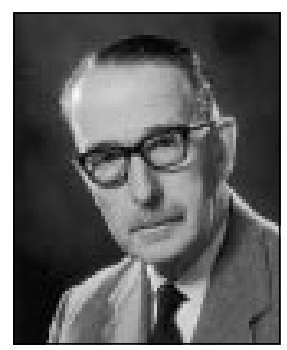

Former general practitioner Worcester for 51 years and consultant anaesthetist ( $b$ Birmingham 1905; $q$ Birmingham 1928), died from prostatic cancer on 25 May 1999. His paternal grandfather was a naval surgeon and an uncle was a general practitioner. He settled in Worcester in 1928, developing his skills as a general practitioner and working for over 38 years as an anaesthetist. A keen committee man, he was on the BMA council during the debate on the NHS Act in 1946, a member of the National Insurance Acts Committee, and the General Medical Services Committee. He had the foresight to propose to the BMA's annual representative meeting in 1945 that general practice should have a training scheme. He was chairman of the local medical committee and of the local BMA division. In advance of the 1965 general practice charter he adapted a Queen Anne building to create a purpose built group practice centre. He was an exact and meticulous doctor and knew his patients well. His major hobby was motor rallying, and for several years he was a works driver for the Morgan team, with whom he won the RAC International Rally team prize for two years in the 1950 s. His later years were complicated by blindness which he accepted with fortitude but retained his sense of humour. Predeceased by his wife, Alice, he leaves two sons (one a general practitioner); five grandchildren (one a general practitioner); and five great grandchildren. [STUART KING, RoBIN STEEL]

\section{Alistair McElderry Turnbull}

General practitioner Kendal, Cumbria ( $b$ India 1917; $q$ Edinburgh 1939), died from a heart attack on 26 December 1999. After house jobs in Edinburgh, Stirling, and Carlisle he joined the Royal Air Force Voluntary Reserve as a medical officer, serving in England, India, and Burma. He ended with the rank of squadron leader. In 1947 he started in general practice and was in Kendal for 31 years. He served on the Westmorland Executive Council and the local medical committee, and was chairman of the Westmorland division of the BMA for a year. He retired in 1978 when his wife was terminally ill and after she died did not return to practice. Outside medicine his main interest was in the church; he was an elder in the United Reform Church and served as session clerk and then church secretary in Kendal. He was a member of Kendal Probus Club. Predeceased by his wife, Jean, he leaves two daughters; a son; and a grandson. [Alistair McElderry Turnbull]

\section{Roland Charles Uren}

General practitioner Bournemouth ( $b$ Wandsworth 1937; q Kings College/ Westminster Hospital 1961), died from carcinoma of the pancreas on 7 December 1999. He entered general practice in 1963 , at first in a partnership of two, which later grew to a training practice of five doctors. $\mathrm{He}$ was conscientious with an ability to communicate and was particularly interested in the general practice training of students at the medical school in Southampton. He held office for several years in the East Dorset division of the BMA and was president of the Bournemouth and Poole Medical Society. Roland enjoyed gardening, golf, and travel, and had a strong Christian faith. $\mathrm{He}$ leaves a wife, Joan; two sons and a daughter; and four grandchildren. [J G NichOLSON]

\section{Michael Treharne Wade}

Former general practitioner Risca, Gwent, 1946-86 (b Risca 1920; $q$ St Thomas's 1944), $d 21$ December 1999. He served in the army for two years before joining his father in practice. Their joint service to the community spanned 85 years. Throughout his career he held slightly radical views-for example, he was a keen exponent and practitioner of spinal manipulation by the Cyriax techniques. He was active in medical politics, serving on many committees, and was interested in promoting the training of future general practitioners. He is remembered for his relaxed, unconventional dressing and his ready sense of humour. Outside medicine he was a keen fisherman and involved himself in many local affairs. He was particularly concerned to see the River Ebbw clean enough to allow trout fishing, which it now is. After retirement he took up wood carving and continued to study German until he became too forgetful. Predeceased by his wife, Diana, who gave him his love of fishing and shared his love of the countryside, he leaves five children and nine grandchildren, with a doctor in each generation. [DTW]

\section{Kathleen Warin}

Former assistant medical officer, department of public health, Oxford, 1948-78 ( $b$ Bingley 1908; $q$ Leeds 1933; DPH), $d 19$ September 1999. She was deputy medical officer of health in Keighley before moving to Oxford, where her husband, John Warin, was medical officer of health, 1948-74. Kathleen was a deeply spiritual person with a sound knowledge of theology and philosophy. She read widely and related to people of all ages. Since 1948 she had lived in the village of Iffley, where she was much loved and a loyal member of the church. Predeceased by her husband and one child, she leaves two daughters; a son (a dermatologist); eight grandchildren; and 10 great grandchildren. [ANDREW WARIN]

\section{Diane Elizabeth Killcross}

General practitioner Gorleston, Norfolk, 1979-99 (b 1952; $q$ Liverpool 1976), died suddenly on 29 December 1999 . Her interests included walking her four dogs and many holidays in exotic locations. [VISH KINI] 